\title{
Can L-carnitine prevent Cadmium-Induced Damage of the Developing Hippocampus?
}

\section{Original Article}

\author{
Ayman S. Amer, Faten Y. Mahmoud, Ashraf H. Abd El-Hakem, Mariam W. Fedal
}

Department of Human Anatomy and Embryology, Faculty of Medicine, Assiut University, Assiut, Egypt

\begin{abstract}
Background: Cadmium is used in everyday life aspects. Hippocampus plays important role in the memory process and could be affected by cadmium exposure. L-carnitine is antioxidant, its role in neuroprotection is still not known.

Aim of Work: To assess effects of pre- and postnatal cadmium exposures on structure of principle cells (pyramidal and granular) of hippocampus in albino rats, and the potential role of L-carnitine.

Material and Methods: Pregnant female albino rats were used and divided into two major groups: I- Pregnancy and IILactation, each was further equally subdivided into 4 subgroups: Group Ia- Control. Group Ib- received cadmium from pregnancy day (PD)10 until delivery. Group Ic- received L-carnitine from PD7 until delivery. Group Id- received both L-carnitine from PD7 + cadmium from PD10 until delivery. Group IIa- Control. Group IIb- received cadmium from day 0-21. Group IIc- received L-carnitine from day 0-21. Group IId- received both L-carnitine+cadmium from day 0-21. Cadmium chloride was given orally by gastric lavage $4 \mathrm{mg} / \mathrm{kg}$ bodyweight/day. L-carnitine dose was given as $200 \mathrm{mg} / \mathrm{kg} / \mathrm{day}$ orally by gastric lavage. The hippocampal specimens were collected from twelve male offspring of both age subgroups (newborn and 21 day old; 96 rats total) and were processed for light, electron microscopy and morphometry.

Results: In cadmium received rats principle cells showed degenerative changes as pyknosis, cytoplasmic vacuoles, damaged mitochondria, indentation of nuclear membrane, and the morphometric data showed highly significant reduction in principle cells number and decreased principle cell layer thickness as compared to control. In cadmium+L-carnitine received rats the principle cells showed a very few swollen cells with little vacuoles, mildly dilated rough endoplasmic reticulum, and the morphometric results were improved approaching those of the control.

Conclusion: cadmium damaged principle cells of dentate gyrus, CA3 and CA1 fields of the rat hippocampus. L-carnitine reduced the cadmium-induced neuronal damage.
\end{abstract}

Received: 03 June 2019, Accepted: 16 July 2019

Key Words: Cadmium, hippocampus, L-carnitine, postnatal study, ultrastructure.

Corresponding Author: Ayman S. Amer, PhD, Department of Human Anatomy and Embryology, Faculty of Medicine, Assiut University, Assiut, Egypt, Tel.: +20 1061461342,E-mail: amer1@live.marshall.edu

ISSN: 1110-0559, Vol. 43, No. 1

\section{INTRODUCTION}

Cadmium is a toxic agent that has many health hazards on human systems and is considered to be a human carcinogen classified as a Group B1 carcinogen by the environmental protection agency $(\mathrm{EPA})^{[1]}$. The central nervous system is especially vulnerable to damage during early neonatal development ${ }^{[2]}$. Cadmium can pass to the fetus via the placenta and was also detected in milk during lactation $^{[3,4,5]}$. Cadmium can enter our bodies through many ways, Food is generally the largest source of cadmium exposure. Cadmium levels in some foods can be increased by the application of phosphate fertilizers or sewage sludge to farm fields ${ }^{[6]}$. The major food groups that contribute to the most cadmium exposure are rice, grains, shellfish, sea food, meat and vegetables ${ }^{[7]}$. Inhalation is another important source of cadmium exposure as it is released in the air during the manufacture of numerous industrial products as pigments, coatings, rechargeable batteries, plastic products and alloys ${ }^{[7,8,9]}$. Smoking is another important source of cadmium exposure ${ }^{[10]}$.

The hippocampus is a part of the limbic located in the medial temporal lobe of the brain ${ }^{[11]}$. It plays important role in the formation of recent memories ${ }^{[12]}$. Development of the hippocampus in rats begins prenatally and continues postnatally. It was found that neurons in the rat hippocampal formation (the dentate gyrus and the hippocampus) are born over a protracted period, from gestational day G 15 into adulthood ${ }^{[13]}$.

L-carnitine has an antioxidant effect and this is attributed to its capability of fatty acid oxidation in the mitochondria to obtain energy ${ }^{[14]}$. L-carnitine is capable of crossing the placental barrier during pregnancy and to be excreted in milk of lactating mothers ${ }^{[15]}$. Accordingly, the aim of this study is to demonstrate the effects of cadmium 
and L-carnitine on the principle cells of the dentate gyrus, CA1 and CA3 fields of the hippocampus of newborn (pregnancy group) and suckling rats (lactation group).

\section{MATERIAL AND METHODS}

\section{Ethics statement}

Handling and care of animals conformed to the guidelines, being in compliance with current national and international laws and policies (NIH Guide for the Care and Use of Laboratory Animals, NIH publication no. 8523, 1985, revised 1996). The experiments were conducted to minimize the number of animals used and suffering caused by the procedures applied in the present study.

\section{Animals}

Albino rats were used in the present study. Through the experiment, the animals were maintained at the animal house under controlled conditions $12 \mathrm{~h}: 12 \mathrm{~h}$ dark/light cycle, normal room temperature and normal humidity and supplied with standard pellet food and tap water. Cadmium chloride was given at a dose of $4 \mathrm{mg} / \mathrm{kg} /$ day dissolved in water and was given orally by gastric lavage daily ${ }^{[16]}$. Cadmium dose is considered sublethal according to $^{[17]}$. L-carnitine was given at a dose of $200 \mathrm{mg} / \mathrm{kg} / \mathrm{day}$ orally by gastric lavage daily according to ${ }^{[18]}$. The animals were divided into 2 groups:

Group I: In this group, 16 female adult albino rats were mated with 8 male adult albino rats, appearance of vaginal plug was considered as day zero of pregnancy. The males were removed from the cages and the females were subjected to the experiment. The pregnant group was subdivided equally into 4 subgroups: Group Ia- Control group: They received no treatment. Group Ib- Cadmium was given at 10th day of pregnancy and was continued daily through the whole period of pregnancy until delivery. Group Ic- (sham control): L-carnitine was given at $7^{\text {th }}$ day of pregnancy and continued daily through the whole period of pregnancy until delivery. Group Id- Cadmium was given at 10th day of pregnancy while L-carnitine was given at 7th day of pregnancy and both were continued daily through the whole period of pregnancy until delivery.

Group II: In this group, 16 female adult albino rats were mated with 8 male adult albino rats. The experiment and treatment started immediately after birth and continued through the whole period of lactation (21 days). Lactation group was subdivided equally into 4 subgroups: Group IIa- Control group: They received no treatment. Group IIbCadmium was given daily to the mothers from day 0 to day 21. Group IIc- (sham control): L-carnitine was given daily to the mothers from day 0 to day 21. Group IId- Both drugs were given daily to the mothers from day 0 to day 21 .

Twelve male rats offspring of both age groups in each of the above subgroups ( 96 rats total) were sacrificed at the end of experiment and studied by different methods (light and electron microscopic study and morphometric study). In this study six rats were used in each subgroup of both age groups for light microscopic study. The brains were quickly removed, fixed in Bouin's solution for 48 hours, dehydrated, embedded in paraffin and the blocks were cut serially in the coronal plane at a thickness of 5 $\mu \mathrm{m}$. The sections were processed for: gallocyanin chrom alum stain ${ }^{[19]}$. Also, six rats were used from the control and experimental subgroups of both ages for electron microscopy of the granular cells of the dentate gyrus and pyramidal cells of hippocampus. The semithin sections were stained with toluidine blue and the ultra-thin sections (450-500 $\mathrm{A}^{\circ}$ ) were stained with uranyl acetate and lead citrate $^{[20]}$. Stained ultrathin sections were examined by Jeol-JEM- 100 CXII Electron Microscope.

\section{Morphometric studies}

In this work the thickness and cell count of granule cells in dentate gyrus and pyramidal cells in CA1 and CA3 regions were measured. Estimation of thickness of the granular cell layer of the dentate gyrus and pyramidal cell layer of CA1 and CA3 fields was done for both groups. Cell count was done by using the Image Analyzer "soft imaging system-Olympus company". The cell count was done on an area of $12360 \mathrm{um}^{2}$ for the granular cells of the dentate gyrus and for the pyramidal cells in the CA3 field and CA1 field in all the studied groups. Data were presented as mean \pm SD. Statistical analysis of data was tested for significance using one way ANOVA and posthoc test "Tukey's" through the computerized statistical package "SPSS"[21]. Finally, significance was considered according to the $P$-value level of significance: $P>0.05 \rightarrow$ no significance. $P<0.05 \rightarrow$ significant. $P<0.01 \rightarrow$ highly significant.

\section{RESULTS}

\section{Newborn rats \\ Dentate gyrus}

Group Ia: Light microscopic study of the newborn hippocampus showed the dentate gyrus granular cell layer composed of densely packed granule cell bodies with small oval to round nuclei (Plate 1.a). The ultrastructural study of the granule cell showed that it has rounded nucleus with clumps of chromatin. The cytoplasm had a lot of mitochondria and free ribosomes. Rough endoplasmic reticulum cisternae were also present (Plate 1.b).

Group Ib: Light microscopic study of the dentate gyrus showed that some granule cells were swollen with vacuolated cytoplasm and darkly stained nuclei (Plate 1.c). Electron microscopic study of the granule cells in this group demonstrated the presence of chromatin condensation of the nucleus. The cytoplasm showed marked loss of free ribosomes, and had dilated rough endoplasmic reticulum and damaged mitochondria (Plate 1.d).

Group Ic: Light microscopic study of the granular cell layer in the dentate gyrus showed that the granule cells were densely packed resembling those of the control (Plate 1.e), thus, Group Ic specimens were not processed for EM study. 
Group Id: Light microscopic study of the granular cell layer in the dentate gyrus showed normal appearance of the majority of the granule cells. A few cells appeared swollen with vacuolated cytoplasm and darkly stained nuclei (Plate 1.f). The ultrastructural study of the granule cell of this group revealed rounded nucleus with condensed chromatin. The cytoplasm contained mitochondria, abundant free ribosomes and dilated rough endoplasmic reticulum (Plate 1.g).

\section{CA3 Field}

Group Ia: Examination of CA3 field of the newborn hippocampus by light microscopy showed the stratum pyramidale composed of several layers of pyramidal neurons. The pyramidal neurons at this age were relatively small and densely packed. The cells had rounded vesicular nuclei (Plate 2.a). The ultrastructural study showed pyramidal cells nuclei with fine granular chromatin and prominent nucleoli. The cytoplasm was rich in organelles as free ribosomes, mitochondria and rough endoplasmic reticulum cisternae (Plate 2.b).

Group Ib: Light microscopic study of the stratum pyramidale of CA3 field showed some of the pyramidal neurons with vacuolated cytoplasmanddarkly stained nuclei. Apparent decrease in the overall cell density of pyramidal neurons was observed (Plate 2.c). The ultrastructural study of CA3 pyramidal neurons demonstrated the presence of nuclear chromatin condensation, and the cytoplasm had many vacuoles, damaged mitochondria and marked loss of free ribosomes (Plate 2.d).

Group Ic: The pyramidal cells of the stratum pyramidale were arranged in several layers. The cells had vesicular nuclei and prominent nucleoli resembling those of the control (Plate 2.e).

Group Id: Examination of the stratum pyramidale of CA3 field showed most of the pyramidal neurons with vesicular nuclei. A very few cells had darkly stained nuclei and vacuolated cytoplasm (Plate 2.f). EM examination of CA3 pyramidal neurons revealed rounded nuclei with fine dispersed granular chromatin. The cytoplasm was rich in free ribosomes, rough endoplasmic reticulum and mitochondria. A few cytoplasmic vacuoles were also seen (Plate 2.g).

\section{CA1 Field}

Group Ia: Semithin sections showed that the stratum pyramidale of CA1 field of the newborn hippocampus was composed of several layers of closely packed pyramidal neurons. In the stratum pyramidale, two zones were distinguished, a deep band of well differentiated pyramidal cells with large spherical nuclei, and a superficial band composed of small spindle shaped less differentiated cells (Plate 3.a). The ultrastructural study of the deep pyramidal cell showed rounded nucleus with evenly distributed chromatin and prominent nucleolus. The cytoplasm was rich in free ribosomes, mitochondria and rough endoplasmic reticulum cisternae (Plate 3.b).
Group Ib: Examination of the stratum pyramidale of the CA1 field showed pyramidal neurons with vacuolated cytoplasm and small-sized pyknotic nuclei (Plate 3.c). Electron microscopic examination of CA1 pyramidal neuron demonstrated the presence of some chromatin clumps in the nucleus. The cytoplasm had vacuoles of variable sizes, dilated rough endoplasmic reticulum, lysosomes, and few free ribosomes (Plate 3.d).

Group Ic: The CA1 field shows the pyramidal cells were densely packed and arranged in several rows similar to those of the control (Plate 3.e).

Group Id: Light microscopic study of the stratum pyramidale of the CA1 field showed several layers of closely packed pyramidal neurons with a few degenerating cells (Plate 3.f). The ultrastructural study showed pyramidal cells nuclei were euchromatic with fine granular chromatin. The cytoplasm contained numerous free ribosomes, mitochondria, a few vacuoles and a few dilated rough endoplasmic reticulum (Plate 3.g).

\section{Presynaptic terminals}

Group Ia: The presynaptic terminal making contact with pyramidal neurons showed the presence of synaptic vesicles of variable sizes and shapes, and mitochondria with well defined cristae (Plate 4.a). Group Ib: Ultrastructural study of presynaptic terminal making contact with pyramidal neuron demonstrated marked loss of synaptic vesicles and the presence of damaged mitochondria (Plate 4.b). Group Id: EM examination of the presynaptic terminal making contact with the pyramidal cell showed synaptic vesicles of variable sizes and shapes (Plate 4.d).

\section{1 day rats}

\section{Dentate gyrus}

Group IIa: The light microscopic study of the 21 day rat hippocampus showed nearly mature appearance with increased thickness of granular cell layer (Plate 5.a). The granule cells had rounded nuclei and were arranged in several rows in the granular cell layer. The molecular layer lied superficial to the granular cell layer while the polymorphic layer was located deep to it (Plate 5.a). EM showed the granule cell containing rounded euchromatic nucleus. The cytoplasm was rich in mitochondria, free ribosomes and rough endoplasmic reticulum (Plate 5.b).

Group IIb: Light microscopic study of granular cell layer showed many cells had darkly stained nuclei with vacuolated cytoplasm (Plate 5.c). The granular cells ultrastructure revealed condensation of chromatin in the nucleus with irregularity and indentation of its nuclear membrane. The cytoplasm showed damaged mitochondria, vacuolization, and loss of ribosomes (Plate 5.d).

Group IIc: Light microscopic examination of the granular cell layer of the dentate gyrus showed cells arranged in several rows and had rounded nuclei similar to those of the control (Plate 5.e). Therefore, Group IIc specimens were not processed for EM study. 
Group IId: Light microscopic study of granular cell layer of the dentate gyrus showed the majority of granular cells had rounded vesicular nuclei. A few granular cells showed vacuolization of the cytoplasm (Plate 5.f). The ultrastructural study of the granular cell showed euchromatic nucleus, surrounded by cytoplasm contained numerous mitochondria, free ribosomes, rough endoplasmic reticulum and a few lysosomes (Plate 5.g).

\section{CA3 field}

Group IIa: Semithin sections showed the pyramidal cell layer in CA3 field of the 21 day rat hippocampus was composed of several layers of closely packed pyramidal neurons with vesicular nuclei and prominent nucleoli (Plate 6.a). The ultrastructural study showed pyramidal cells with large rounded euchromatic nuclei with regular nuclear envelope. The cytoplasm had many mitochondria, free ribosomes and rough endoplasmic reticulum (Plate 6.b).

Group IIb: Light microscopic study showed many pyramidal cells in the CA3 field had darkly stained nuclei and vacuolated cytoplasm (Plate 6.c). The ultrastructural study of the pyramidal cell showed nuclear condensation of chromatin, and the cytoplasm had many vacuoles of variable sizes, degenerated mitochondria and marked loss of free ribosomes (Plate 6.d).

Group IIc: The pyramidal neurons of CA3 field were closely packed, triangular in shape with vesicular nuclei similar to those of the control (Plate 6.e).

Group IId: Light microscopic study of the stratum pyramidale of the CA3 field of the hippocampus showed pyramidal neurons with vesicular nuclei. A few cells with pyknotic nuclei and vacuolated cytoplasm were also found (Plate 6.f). The ultrastructural study of CA3 pyramidal cell showed euchromatic nucleus with widely distributed granular chromatin. The cytoplasm contained many mitochondria, rough endoplasmic reticulum, free ribosomes and a few lysosomes (Plate 6.g).

\section{CA1 field}

Group IIa: Light microscopic study of the pyramidal cell layer in CA1field of the 21 day rat hippocampus demonstrated that pyramidal cells had spherical or oval nuclei and were closely packed in several layers. The pyramidal cells had apical dendrites which projected into stratum radiatum (Plate 7.a). The ultrastructure of the pyramidal cell showed an oval nucleus with prominent nucleoli. The nucleus had fine granular chromatin that was widely distributed. The cytoplasm was rich in mitochondria, free ribosomes, rough endoplasmic reticulum that was arranged in the form of broad cisternae stacked one on top of the other (Plate 7.b).

Group IIb: Light microscopic study of the pyramidal cell layer of the CA1 field showed majority of its cells with darkly stained nuclei and vacuolated cytoplasm (Plate 7.c). The ultrastructural study of CA1 pyramidal neuron showed peripheral condensation of nuclear chromatin. The cytoplasm contained damaged mitochondria, dilated rough endoplasmic reticulum cisternae, and many vacuoles (Plate 7.d).

Group IIc: The pyramidal CA1 neurons had rounded or oval nuclei with prominent nucleoli (Plate 7.e). The structure of pyramidal neurons of CA1 field of this group was closely similar to that of the control.

Group IId: Examination of the stratum pyramidale of CA1 field of the hippocampus showed most of the pyramidal neurons had oval vesicular nuclei with prominent nucleoli (Plate 7.f). The ultrastructural study of CA1 the pyramidal cell showed an oval nucleus with fine granular chromatin and prominent nucleoli. The cytoplasm contained rough endoplasmic reticulum, free ribosomes and numerous mitochondria and a few lysosomes (Plate 7.g).

\section{Presynaptic terminals}

Group IIa: The ultrastructure of presynaptic terminal making contact with the pyramidal cell demonstrated the presence of many synaptic vesicles of variable sizes (Plate 8.a). Group IIb: EM study of the presynaptic terminal making contact with the pyramidal neuron revealed marked decrease in the amount of the synaptic vesicles (Plate 8.b). Group IId: The presynaptic terminal making contact with the pyramidal neuron had many synaptic vesicles of variable shapes and sizes, and appeared closely similar to that of the control (Plate 8.d).

\section{Morphometric results}

\section{Dentate gyrus}

\section{Granular cell layer thickness}

\section{Group I (Newborn rats)}

In Group Ia: the thickness of granular cell layer of dentate gyrus was $51.02 \pm 7.36$ while it was found to be $40.41 \pm 6.25$ in Group Ib. This difference was statistically highly significant $(P<0.01)$. In Group Ic: the granular cell layer thickness was $50.25 \pm 7.84$, with statistically insignificant reduction as compared to the control $(P>0.05)$. In Group Id: the thickness was $43.55 \pm 5$, with statistically highly significant reduction as compared to the control $(P<0.01)$. There was no statistically significant difference in the granular cell layer thickness of Group Id when compared to Group Ib $(P>0.05)$ (Histogram 1).

\section{Group II (21 day rats)}

In Group IIa: the thickness of granular cell layer of dentate gyrus was $70.48 \pm 6.26$ while it was $44.38 \pm 6.35$ in Group IIb. This difference was statistically highly significant $(P<0.01)$. In Group IIc: the granular cell layer thickness was $71.12 \pm 6.19$, with statistically insignificant increase as compared to the control $(P>0.05)$. In Group IId: the thickness was $67.88 \pm 5.37$, with statistically insignificant reduction as compared to the control $(P>0.05)$. There was statistically highly significant increase in the granular cell layer thickness in Group IId when compared to Group IIb $(\mathrm{P}<0.01)$ (Histogram 1). 


\section{Granular cell count}

\section{Group I (Newborn rats)}

In Group Ia: the number of granular cells in dentate gyrus per area of $12360 \mu^{2}$ was $149.75 \pm 5.81$ while it was $116.89 \pm 6.13$ in Group Ib. This difference was statistically highly significant $(P<0.01)$. In Group Ic: the granular cell number was $151.72 \pm 6.31$, with statistically insignificant increase as compared to the control $(P>0.05)$. In Group Id: the granular cell number was $144.22 \pm 5.23$, with statistically insignificant reduction as compared to the control $(P>0.05)$. There was statistically highly significant increase in the granular cell number in Group Id when compared to Group $\mathrm{Ib}(P<0.01)$. (Histogram 2$)$.

\section{Group II (21 day rats)}

In Group IIa: the number of granular cells in dentate gyrus per area of $12360 \mu^{2}$ was $91.47 \pm 4.53$ while it was found to be $58.14 \pm 6.49$ in Group IIb. This difference was statistically highly significant $(P<0.01)$. In Group IIc: the number of granular cells was $92.97 \pm 2.90$, with statistically insignificant increase as compared to the control $(P>0.05)$. In Group IId: the granular cell number was $95.56 \pm 6.26$, with statistically insignificant increase as compared to the control $(P>0.05)$. There was statistically highly significant increase in the granular cell number in Group IId when compared to Group IIb $(P<0.01)$ (Histogram 2).

\section{CA3 field}

\section{Pyramidal cell layer thickness}

\section{Group I (Newborn rats)}

In Group Ia: the thickness of stratum pyramidale of CA3 field was $117.75 \pm 23.72$ while it was $83.67 \pm 12.68$ in Group Ib. This difference was statistically highly significant $(P<0.01)$. In Group Ic: the thickness was $112.78 \pm 13.46$, with statistically insignificant reduction as compared to the control $(P>0.05)$. In Group Id: the thickness was $117.39 \pm 14.19$, with statistically insignificant reduction as compared to the control $(P>0.05)$. There was statistically highly significant increase in thickness of stratum pyramidale in Group Id when compared to Group Ib $(P<0.01)$ (Histogram 3).

\section{Group II (21 day rats)}

In Group IIa: the thickness of stratum pyramidale of CA3 field was $67.82 \pm 5.28$ while it was found to be $44.92 \pm 5.71$ in Group IIb. This difference was statistically highly significant $(P<0.01)$. In Group IIc: the thickness was $68.39 \pm 3.40$, with statistically insignificant increase as compared to the control $(P>0.05)$. In Group IId: the thickness was $63.78 \pm 3.47$, with statistically insignificant reduction as compared to the control $(P>0.05)$. There was statistically highly significant increase in thickness of stratum pyramidale in Group IId when compared to Group IIb $(P<0.01)($ Histogram 3).

\section{Pyramidal cell count \\ Group I (Newborn rats)}

In Group Ia: the number of pyramidal cells in CA3 field per area of $12360 \mu^{2}$ was $147.53 \pm 5.92$ while it was $76.67 \pm 7.11$ in Group Ib. This difference was statistically highly significant $(P<0.01)$. In Group Ic: the pyramidal cell number was $146.25 \pm 7.93$, with statistically insignificant reduction as compared to the control $(P>0.05)$. In Group Id: the number of pyramidal cells was $145.58 \pm 5.21$, with statistically insignificant reduction as compared to the control $(P>0.05)$. There was statistically highly significant increase in the pyramidal cell number in Group Id when compared to Group Ib $(P<0.01)$ (Histogram 4).

\section{Group II (21 day rats)}

In Group IIa: the number of pyramidal cells in CA3 field per area of $12360 \mu^{2}$ was $59.42 \pm 3.32$, while it was found to be $35.56 \pm 4.46$ in Group IIb. This difference was statistically highly significant $(P<0.01)$. In Group IIc: the pyramidal cell number was $61.58 \pm 2.29$, with statistically insignificant increase as compared to the control $(P>0.05)$. In Group IId: the number of pyramidal cells was $59.00 \pm 3.79$, with statistically insignificant reduction as compared to the control $(P>0.05)$. There was statistically highly significant increase in the pyramidal cell number in Group IId when compared to Group IIb $(P<0.01)$ (Histogram 4).

\section{CA1 field}

\section{Pyramidal cell layer thickness}

\section{Group I (Newborn rats)}

In Group Ia: the thickness of stratum pyramidale of CA1 field was $101.95 \pm 12.15$ while it was found to be $76.95 \pm 10.06$ in Group Ib. This difference was statistically highly significant $(P<0.01)$. In Group Ic: the thickness was $116.31 \pm 11.30$, with statistically highly significant increase as compared to the control $(P<0.01)$. In Group Id: the thickness was $114.63 \pm 20.66$, with statistically highly significant increase as compared to the control $(P<0.01)$. Moreover, there was statistically highly significant increase in thickness of stratum pyramidale in Group Id when compared to Group $\mathrm{Ib}(P<0.01)$. (Histogram 5).

\section{Group II (21 day rats)}

In Group IIa: the thickness of stratum pyramidale of CA1 field was $52.37 \pm 3.83$ while it was found to be $41.19 \pm 5.60$ in Group IIb. This difference was statistically highly significant $(P<0.01)$. In Group IIc: the thickness was $53.10 \pm 4.20$, with statistically insignificant increase as compared to the control $(P>0.05)$. In Group IId: the thickness was $53.47 \pm 4.86$, with statistically insignificant increase as compared to the control $(P>0.05)$. There was statistically highly significant increase in thickness of stratum pyramidale in Group IId when compared to Group IIb $(P<0.01)$. (Histogram 5). 


\section{Pyramidal cell count}

\section{Group I (Newborn rats)}

In Group Ia: the number of pyramidal cells in CA1 field per area of $12360 \mu^{2}$ was $114.94 \pm 6.47$ while it was $71.00 \pm 6.22$ in Group Ib. This difference was statistically highly significant $(P<0.01)$. In Group Ic: the pyramidal cell number was $117.61 \pm 6.62$, with statistically insignificant increase as compared to the control $(P>0.05)$. In Group Id: the number of pyramidal cells was $115.06 \pm 9.21$, with statistically insignificant increase as compared to the control $(P>0.05)$. There was statistically highly significant increase in the pyramidal cell number in Group Id when compared to Group Ib $(P<0.01)$ (Histogram 6).

\section{Group II (21 day rats)}

In Group IIa: the number of pyramidal cells in CA1 field per area of $12360 \mu^{2}$ was $35.67 \pm 2.15$ while it was found to be $24.81 \pm 3.45$ in Group IIb. This difference was statistically highly significant $(P<0.01)$. In Group IIc: the pyramidal cell number was $37.58 \pm 2.12$, with statistically insignificant increase as compared to the control $(P>0.05)$. In Group IId: the number of pyramidal cells was $34.78 \pm 2.50$, with statistically insignificant reduction as compared to the control $(P>0.05)$. There was statistically highly significant increase in the pyramidal cell number in Group IId when compared to Group IIb $(P<0.01)$ (Histogram 6)

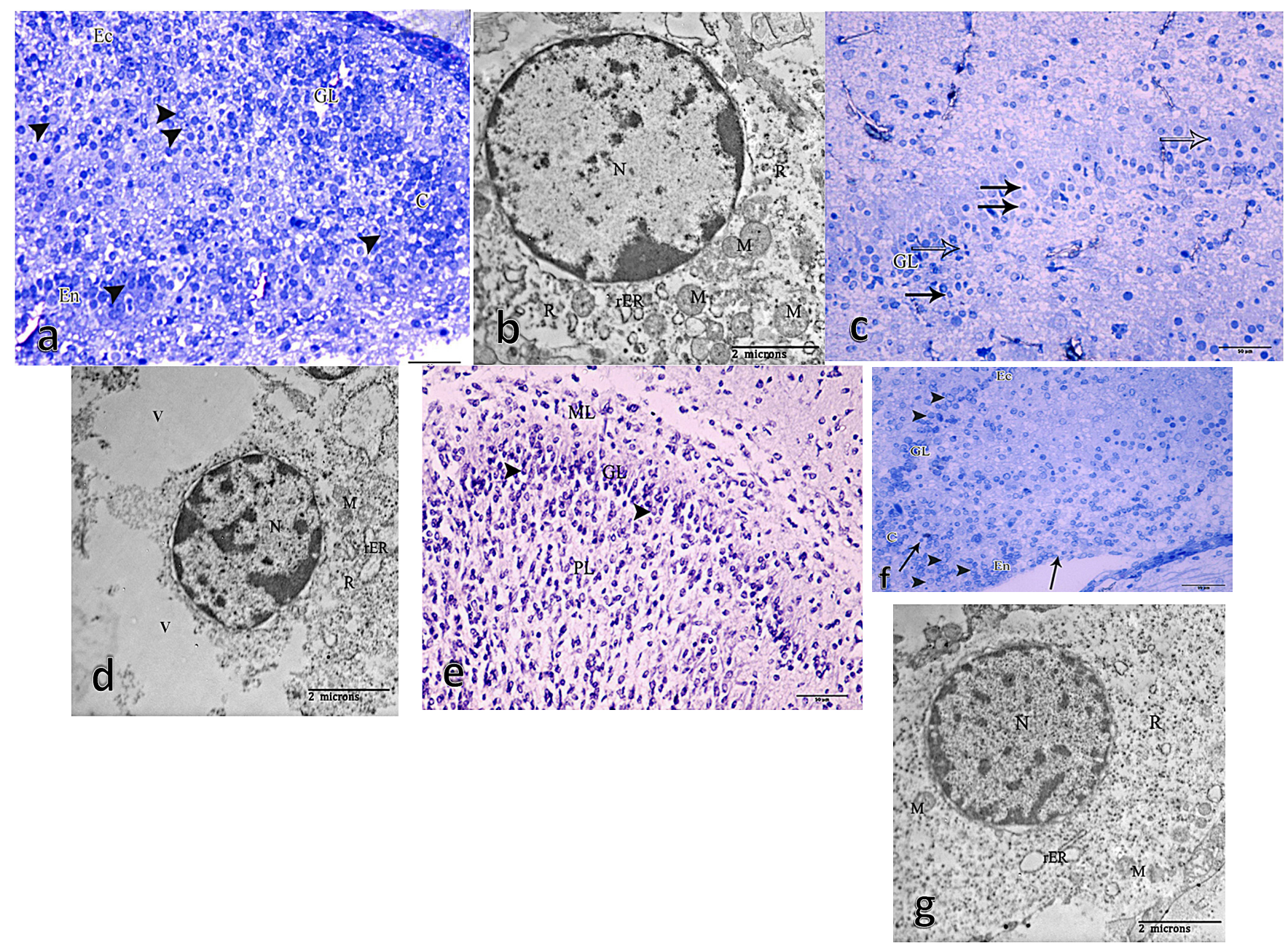

Plate 1: a: A photomicrograph of a semithin section of the dentate gyrus of the hippocampus of newborn control rat showing the granular cell layer (GL) The granule cells are densely packed and have rounded nuclei (arrow heads). The ectal limb (Ec), endal limb (En), and crest (C) parts of the dentate gyrus are also seen (Toluidine blue, $\mathrm{x} 400$ ). b: A transmission electron micrograph of a granule cell of the dentate gyrus of newborn control rat showing the granule cell with a rounded nucleus $(\mathrm{N})$ and chromatin clumps. The surrounding cytoplasm contains numerous mitochondria (M), rough endoplasmic reticulum (rER) and free ribosomes (R). (TEM, x10000). c: A photomicrograph of a semithin section of the dentate gyrus of the hippocampus of newborn rat treated with cadmium showing the granular cell layer (GL). Some granule cells appear swollen with vacuolated cytoplasm (arrows). Other cells have small-sized pyknotic nuclei (open arrows). (Toluidine blue, $\mathrm{x} 400$ ). $\mathrm{d}$ : An electron photomicrograph of the granule cell in newborn rat treated with cadmium. The nucleus (N) of cell shows chromatin condensation. The cytoplasm appears to be rarified. It has big vacuoles (V), some dilated rough endoplasmic reticulum (rER) and damaged mitochondria (M). Marked loss of free ribosomes (R) can be observed. (TEM, x10000). e: A photomicrograph of a coronal section of the dentate gyrus of the hippocampus of newborn rat treated with L-carnitine alone showing granular cell layer (GL). It contains densely packed granule cells (arrow heads). The molecular layer (ML) and polymorphic layer (PL) are also seen. (Gallocyanin, x400). f: A photomicrograph of a semithin section of the dentate gyrus of the hippocampus of newborn rat treated with both cadmium and L-carnitine showing the granular cell layer (GL), ectal limb (Ec), endal limb (En), and crest (C) parts of the dentate gyrus. The majority of granule cells appear densely packed and have rounded nuclei (arrow heads). Note the presence of a few cells with vacuolated cytoplasm and darkly stained nuclei (arrows). (Toluidine blue, x400). g: An electron photomicrograph of the granule cell of the dentate gyrus of newborn rat treated with both cadmium and L-carnitine. It shows the granule cell with a rounded nucleus (N) and condensed chromatin. The surrounding cytoplasm contains mitochondria (M), many free ribosomes $(\mathrm{R})$ and dilated rough endoplasmic reticulum (rER). (TEM, x10000). 

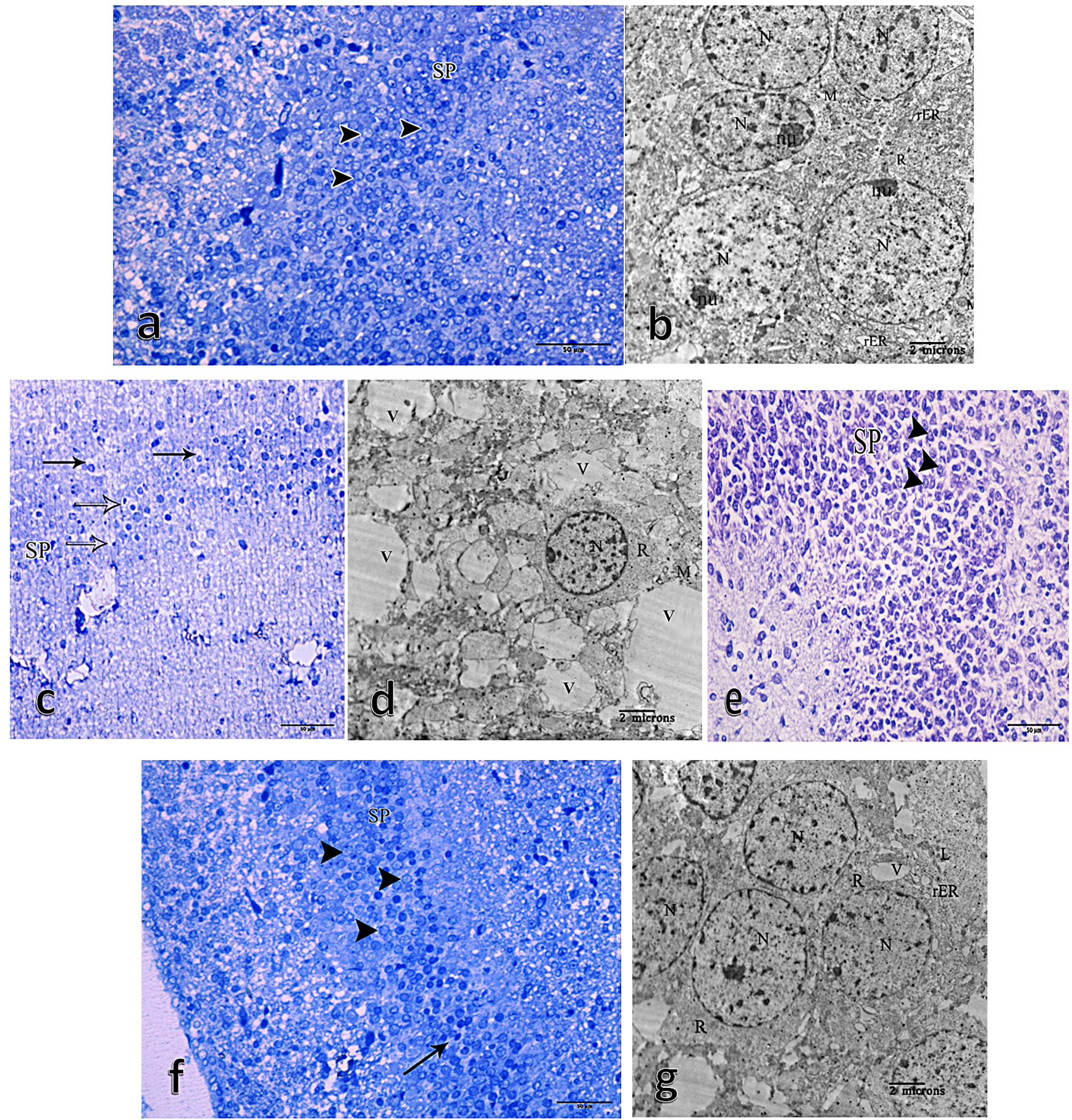

Plate 2: a: A photomicrograph of a semithin section of CA3 field of the hippocampus of newborn control rat showing the stratum pyramidale (SP) in which the cells are arranged in several layers. The pyramidal neurons are densely packed (arrow heads). They have rounded vesicular nuclei with prominent nucleoli. (Toluidine blue, $\mathrm{x} 400$ ). b: An electron photomicrograph of the pyramidal cells of the CA3 field of newborn control rat. It shows the pyramidal cells with rounded nucleoli $(\mathrm{N})$, fine granular chromatin and prominent nucleoli $(\mathrm{nu})$. The cytoplasm contains numerous mitochondria (M) and many free ribosomes (R). Some rough endoplasmic reticulum (rER) cisternae are also present. (TEM, x3600). c: A photomicrograph of a semithin section of the CA3 field of the hippocampus of newborn rat treated with cadmium. It shows the presence of many pyramidal cells in the stratum pyramidale (SP) with vacuolated cytoplasm (arrows). Some cells have small-sized pyknotic nuclei (open arrows). (Toluidine blue, x400). d: An electron photomicrograph of a pyramidal cell in CA3 field in newborn rat treated with cadmium. The nucleus $(\mathrm{N})$ shows chromatin condensation. The cytoplasm contains many vacuoles (V) of variable size. Note the decrease in the amount of free ribosomes (R) and the presence of damaged mitochondria (M). (TEM, x3600). e: A photomicrograph of a coronal section of the CA3 field of the hippocampus of newborn rat treated with L-carnitine alone showing the stratum pyramidale (SP) contains densely packed pyramidal cells. The cells have vesicular nuclei with prominent nucleoli (arrow heads). They appear closely similar to those of the control group. (Gallocyanin, $\mathrm{x} 400$ ). f: A photomicrograph of a semithin section of CA3 field of the hippocampus of newborn rat treated with both cadmium and L-carnitine showing the stratum pyramidale (SP) in which most of the pyramidal neurons are having vesicular nuclei with prominent nucleoli (arrow heads). Note the presence of a few cells with vacuolated cytoplasm and darkly stained nuclei (arrow). (Toluidine blue, x400). g: An electron photomicrograph of the pyramidal cell of CA3 field of newborn rat treated with both cadmium and L-carnitine. It shows the pyramidal cells have rounded nuclei (N) with fine dispersed granular chromatin. The surrounding cytoplasm contains dilated rough endoplasmic reticulum (rER), free ribosomes (R), lysosomes (L) and some vacuoles (V). (TEM, x3600). 

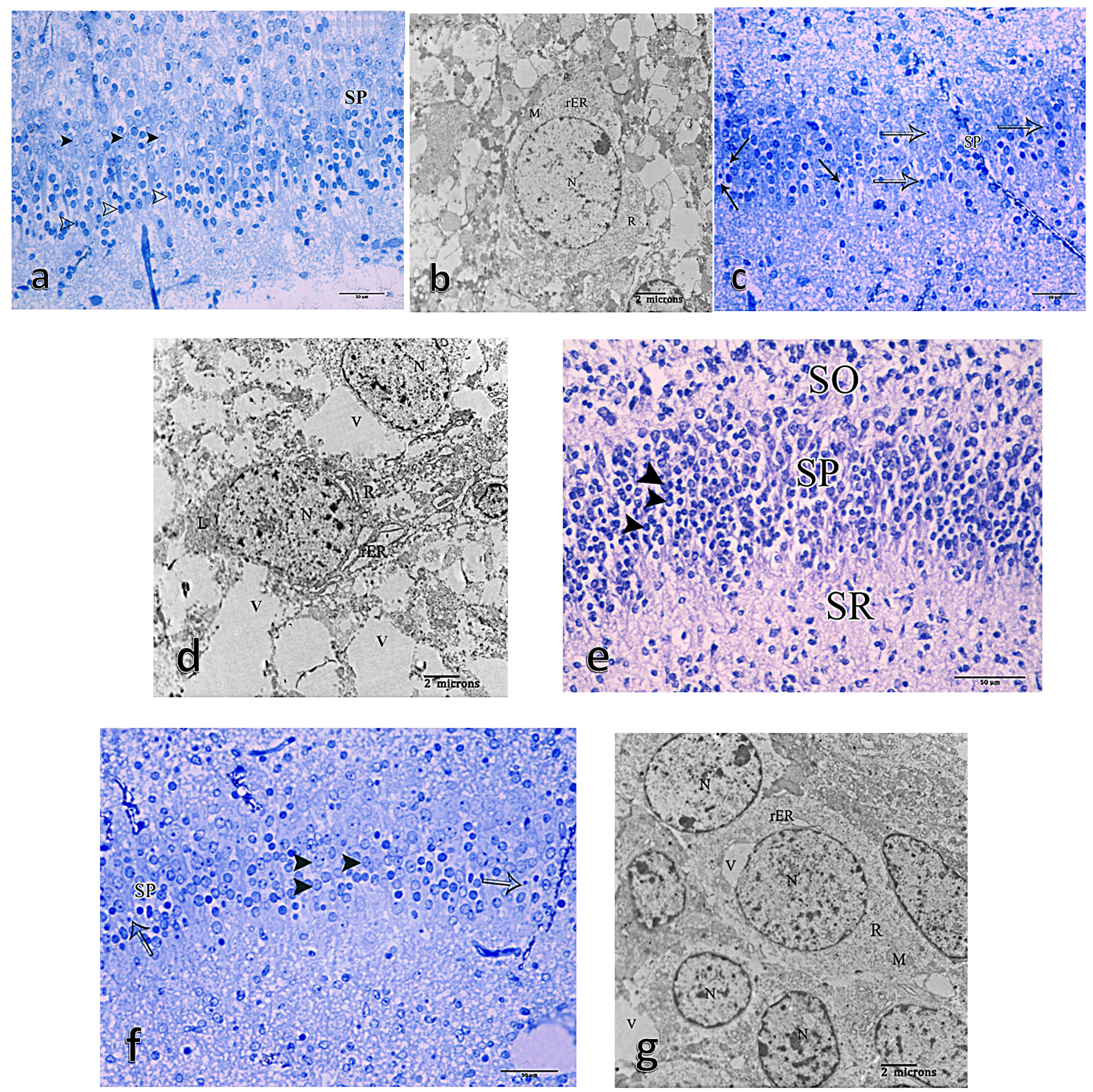

Plate 3: a: A photomicrograph of a semithin section of CA1 field of the hippocampus of newborn control rat showing the stratum pyramidale (SP) in which pyramidal cells are arranged in several layers. The pyramidal neurons can be distinguished into two zones, the deep zone showing well differentiated cells with vesicular nuclei (arrow heads), while the superficial zone showing spindle shaped less differentiated cells (open arrow heads). (Toluidine blue, $\mathrm{x} 400$ ). b: An electron photomicrograph of the pyramidal cell of the CA1 field of newborn control rat showing an oval euchromatic nucleus (N). The surrounding cytoplasm has mitochondria $(\mathrm{M})$, free ribosomes $(\mathrm{R})$ and rough endoplasmic reticulum (rER). (TEM, x3600). c: A photomicrograph of a semithin section of the CA1 field of the hippocampus of newborn rat treated with cadmium showing the stratum pyramidale (SP) containing pyramidal neurons of which some appear swollen with vacuolated cytoplasm (arrows), while other pyramidal neurons appear with small-sized pyknotic nuclei (open arrows). (Toluidine blue, $\mathrm{x} 400)$. $\mathrm{d}$ : An electron photomicrograph of a pyramidal cell in CA1 field in newborn rat treated with cadmium. The nucleus (N) shows chromatin clumps. The cytoplasm shows dilated rough endoplasmic reticulum (rER), lysosomes (L), vacuoles of variable size (V), and marked loss of free ribosomes (R). (TEM, x3600). e: A photomicrograph of a coronal section of the CA1 field of the hippocampus of newborn rat treated with L-carnitine alone showing the stratum pyramidale (SP) containing densely packed pyramidal cells arranged in several layers (arrow heads) resembling those of the control group. The stratum oriens (SO) and stratum radiatum (SR) are also seen. (Gallocyanin, $\mathrm{x} 400$ ). f: A photomicrograph of a semithin section of CA1 field of the hippocampus of newborn rat treated with both cadmium and L-carnitine showing the stratum pyramidale (SP) in which the majority of pyramidal neurons having vesicular nuclei (arrow heads). A few cells with pyknotic nuclei are seen (open arrows). (Toluidine blue, x400). g: An electron photomicrograph of the pyramidal cell of CA1 field of newborn rat treated with both cadmium and L-carnitine. It shows the pyramidal cells with round to oval nuclei $(\mathrm{N})$. The surrounding cytoplasm is rich in organelles as mitochondria (M), and free ribosomes (R). Note the presence of dilated rough endoplasmic reticulum (rER) and a few vacuoles (V). (TEM, x3600). 

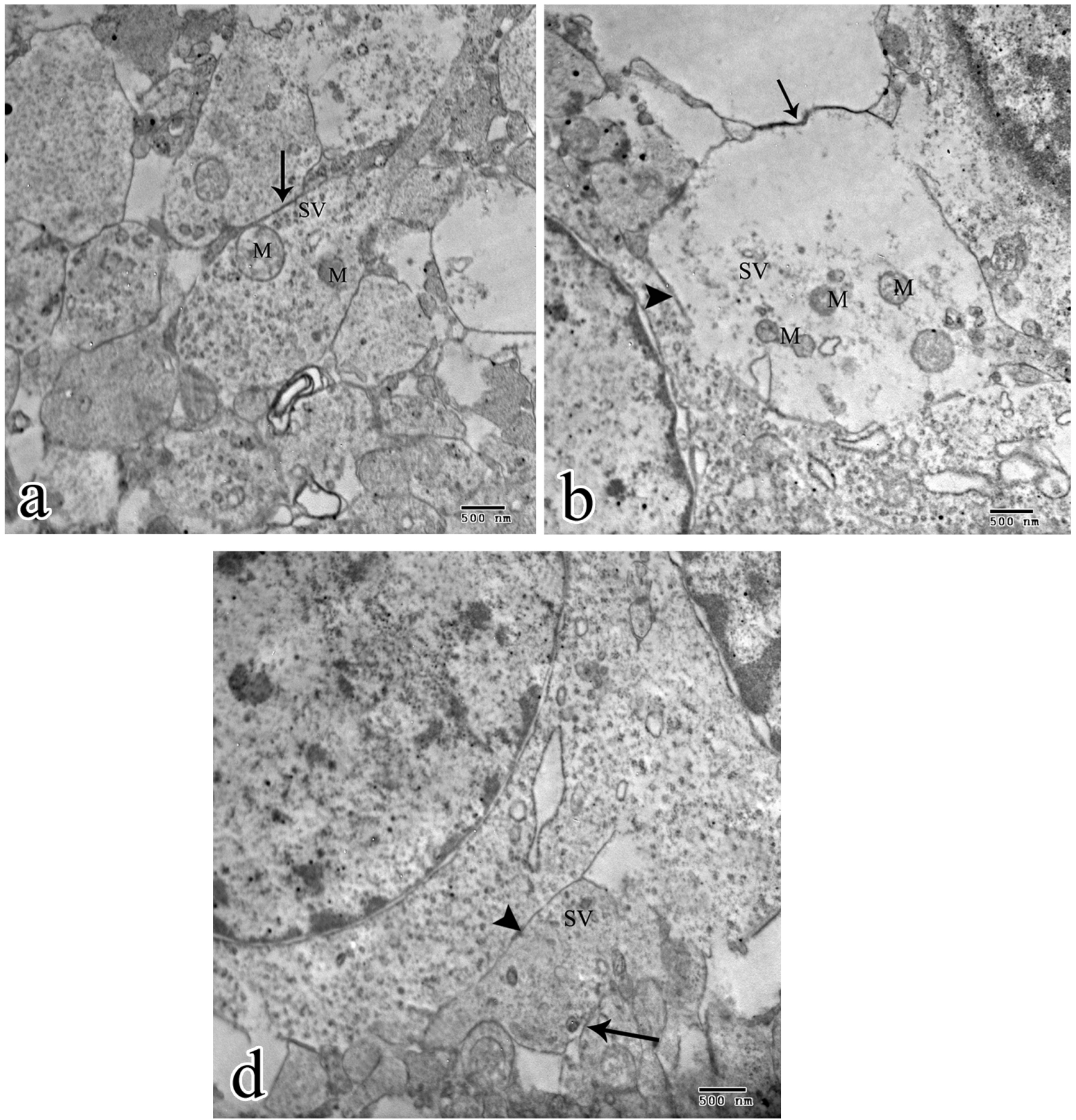

Plate 4: a: An electron photomicrograph showing presynaptic terminal (arrow) making synaptic contact with a pyramidal cells of newborn control rat. The presynaptic terminal has a lot of synaptic vesicles (SV) and mitochondria (M). (TEM, x14000). b: An electron photomicrograph shows presynaptic terminal (arrow) making synaptic contact (arrow head) with pyramidal cell in newborn rat treated with cadmium. Note the marked decrease in the amount of synaptic vesicles (SV) and presence of damaged mitochondria (M). (TEM, x14000). d: An electron photomicrograph showing synaptic contact (arrow head) between presynaptic terminal (arrow) and pyramidal cell of newborn rat treated with both cadmium and L-carnitine. Note that the presynaptic terminal is filled with many synaptic vesicles (SV). (TEM, x14000). 

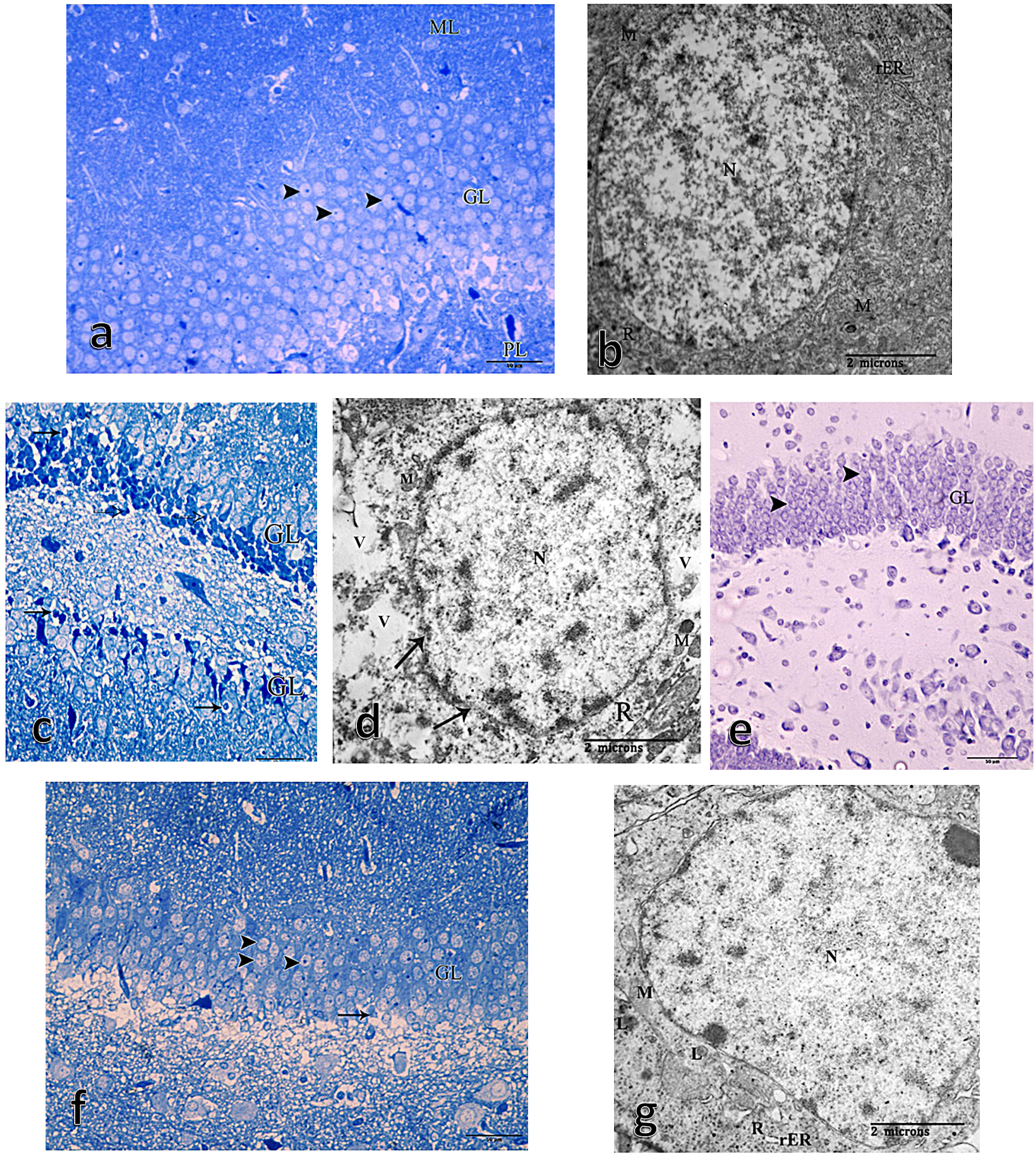

Plate 5: a: A photomicrograph of a semithin section of the dentate gyrus of 21 day old control rat showing the granule cells are arranged in several rows in the granular cell layer (GL). The granule cells have large rounded vesicular nuclei (arrow heads). Note that the molecular layer (ML) is superficial to the granular cell layer (GL), while the polymorphic layer (PL) lies deep to it. (Toluidine blue, $\mathrm{x} 400$ ). b: An electron photomicrograph of the granule cells of the dentate gyrus of 21 day old control rat. It shows the granule cell with a round to oval euchromatic nucleus (N). The cytoplasm contains numerous mitochondria (M), rough endoplasmic reticulum (rER) and free ribosomes (R). (TEM, x10000). c: A photomicrograph of a semithin section of the dentate gyrus of 21 day old rat treated with cadmium. It shows the granular cell layer (GL) had majority of its granule cells with darkly stained nuclei (arrows). Some cells have vacuolated cytoplasm and small-sized nuclei (open arrows). (Toluidine blue, x400). d: An electron photomicrograph of the granule cell in 21 day old rat treated with cadmium showing degeneration with chromatin condensation of the nucleus $(\mathrm{N})$ and indentation of the nuclear membrane (arrows). The cytoplasm shows many vacuoles (V), marked loss of free ribosomes (R) and damaged mitochondria (M). (TEM, x10000). e: A photomicrograph of a coronal section of the dentate gyrus of the hippocampus of 21 day old rat treated only with L-carnitine showing granular cell layer (GL) in which the granule cells appear normal with large round vesicular nuclei and prominent nucleoli (arrow heads). (Gallocyanin, x400). f: A photomicrograph of a semithin section of the dentate gyrus of 21 day old rat treated with both cadmium and L-carnitine. It shows granule cells with large round vesicular nuclei and prominent nucleoli (arrow heads) in the granular cell layer (GL). Note the presence of a very few cells with small-sized nuclei and vacuolated cytoplasm (arrow). (Toluidine blue, x400). g: An electron photomicrograph of the granule cell of the dentate gyrus of 21 day old rat treated with both cadmium and L-carnitine. It shows the granule cell with an euchromatic nucleus $(\mathrm{N})$ and prominent nucleoli. The cytoplasm contains numerous mitochondria (M), rough endoplasmic reticulum (rER), free ribosomes (R) and a few lysosomes (L). (TEM, x10000). 

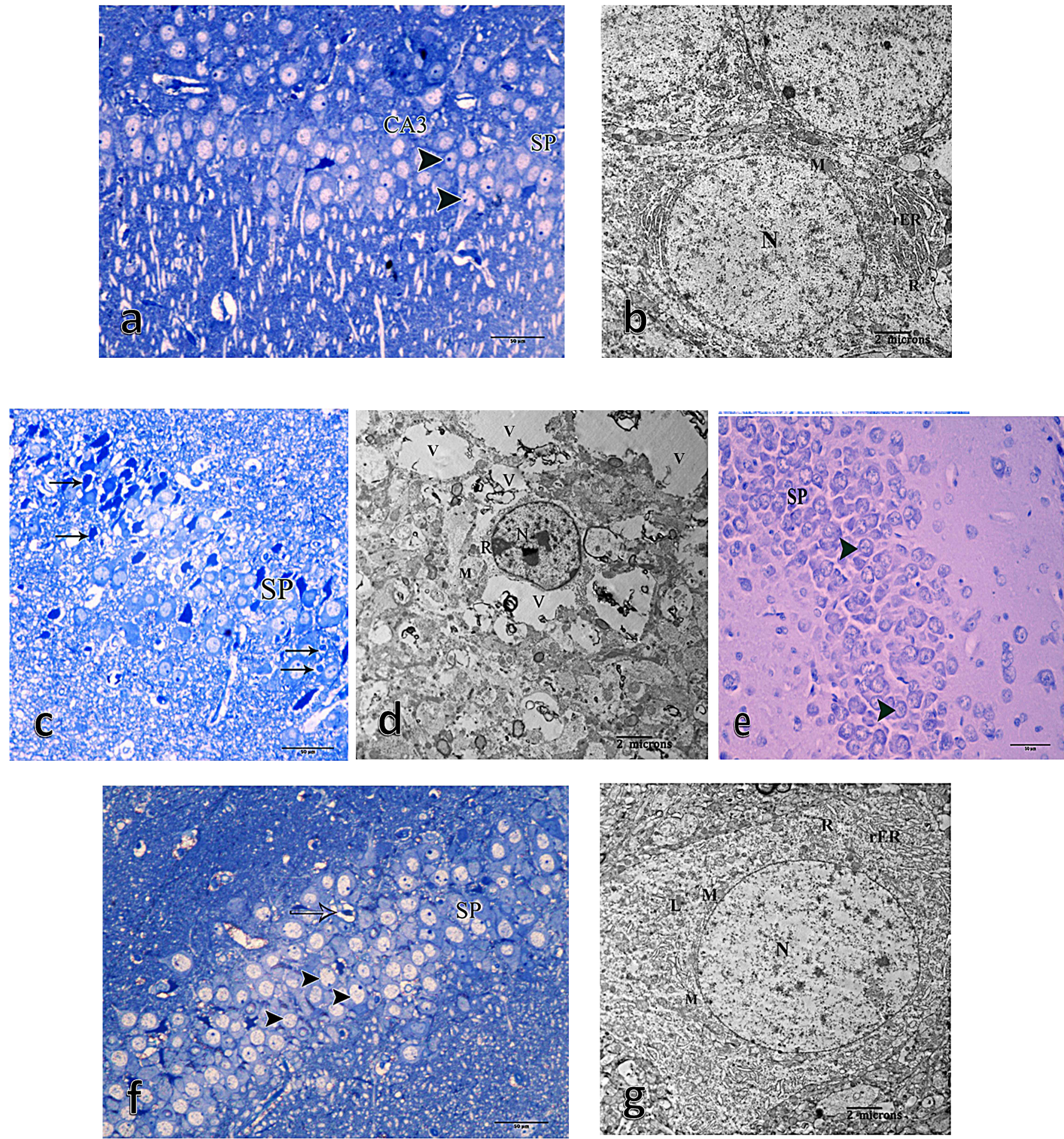

Plate 6: a: A photomicrograph of a semithin section of CA3 field of the hippocampus of 21 day old control rat showing the stratum pyramidale (SP). The pyramidal neurons are triangular in shape. They have large rounded vesicular nuclei (arrow heads) with prominent nucleoli. (Toluidine blue, $\mathrm{x} 400$ ). $\mathrm{b}$ : An electron photomicrograph of the pyramidal cells of the CA3 field of 21 day old control rat showing pyramidal cell with rounded nucleus (N) and evenly distributed fine granular chromatin. The cytoplasm contains mitochondria (M), free ribosomes (R) and rough endoplasmic reticulum cisternae (rER). (TEM, x3600). c: A photomicrograph of a semithin section of CA3 field of 21 day old rat treated with cadmium. It shows many of the pyramidal cells in the stratum pyramidale (SP) have darkly stained nuclei and vacuolated cytoplasm (arrows). (Toluidine blue, x400). d: An electron photomicrograph of a pyramidal cell in CA3 field in 21 day old rat treated with cadmium showing chromatin condensation of the nucleus (N). The cytoplasm has many vacuoles (V) of variable sizes, degenerated mitochondria (M) with apparent decrease in free ribosomes (R). (TEM, x3600). e: A photomicrograph of a coronal section of the CA3 field of the hippocampus of 21 day old rat treated with L-carnitine showing stratum pyramidale (SP) in which the pyramidal cells appear normal with large vesicular nuclei and prominent nucleoli (arrow heads). (Gallocyanin, x400). f: A photomicrograph of a semithin section of CA3 field of 21 day old rat treated with both cadmium and L-carnitine showing the majority of cells with large vesicular nuclei and prominent nucleoli (arrow heads) in the stratum pyramidale (SP). A few cells have pyknotic nuclei and vacuolated cytoplasm (open arrow). (Toluidine blue, $\mathrm{x} 400$ ). g: An electron photomicrograph of the pyramidal cell of CA3 field of 21 day old rat treated with both cadmium and L-carnitine showing the pyramidal cell with rounded euchromatic nucleus (N). The surrounding cytoplasm contains numerous mitochondria (M), rough endoplasmic reticulum (rER), free ribosomes (R) and a few lysosomes (L). (TEM, x3600). 

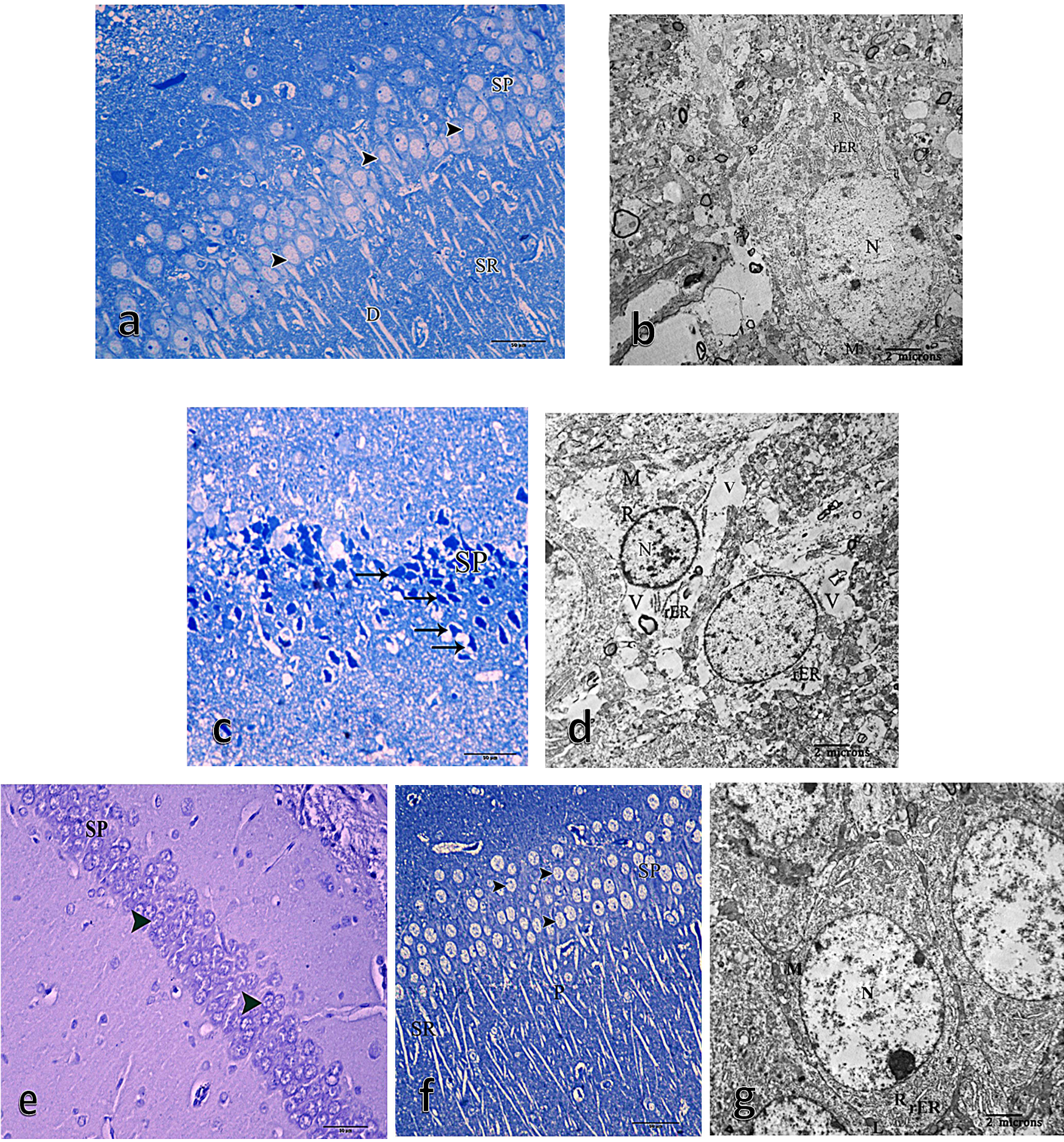

Plate 7: a: A photomicrograph of semithin section of CA1 field of the hippocampus of 21 day old control rat showing the stratum pyramidale (SP) in which the pyramidal cells have large oval vesicular nuclei (arrow heads) with some prominent nucleoli. The apical dendrites (D) are seen emerging from the cells passing toward the stratum radiatum (SR). (Toluidine blue, $\mathrm{x} 400$ ). b: An electron photomicrograph of the pyramidal cells of the CA1 field of 21 day old control rat showing an oval nucleus $(\mathrm{N})$ with nucleoli. The cytoplasm is rich in mitochondria $(\mathrm{M})$, rough endoplasmic reticulum (rER) and free ribosomes (R). (TEM, $\mathrm{x} 3600$ ). c: A photomicrograph of a semithin section of CA1 field of 21 day old rat treated with cadmium showing the stratum pyramidale (SP) with the majority of its pyramidal neurons have darkly stained nuclei and vacuolated cytoplasm (arrows). (Toluidine blue, $\mathrm{x} 400$ ). d: An electron photomicrograph of a pyramidal cell of CA1 field of 21 day old rat treated with cadmium showing nucleus $(\mathrm{N})$ with peripheral chromatin condensation. The cytoplasm contains many vacuoles (V), damaged mitochondria (M), some dilated rough endoplasmic reticulum cisternae (rER) and apparent decrease in free ribosomes (R). (TEM, x3600). e: A photomicrograph of a coronal section of the CA1 field of the hippocampus of 21 day old rat treated with L-carnitine showing the stratum pyramidale (SP) with pyramidal neurons have large oval vesicular nuclei (arrow heads). (Gallocyanin, x400). f: A photomicrograph of a semithin section of CA1 field of 21 day old rat treated with both cadmium and L-carnitine showing the stratum pyramidale (SP) in which the pyramidal cells have large oval vesicular nuclei (arrow heads). Prominent nerve processes (P) emerge from the cells and pass toward the stratum radiatum (SR). (Toluidine blue, $\mathrm{x} 400)$. g: An electron photomicrograph of the pyramidal cell of CA1 field of 21 day old rat treated with both cadmium and L-carnitine showing the pyramidal cell with an oval nucleus (N) and prominent nucleoli. The surrounding cytoplasm contains numerous mitochondria (M), rough endoplasmic reticulum (rER), free ribosomes (R) and a few lysosomes (L). (TEM, x3600). 

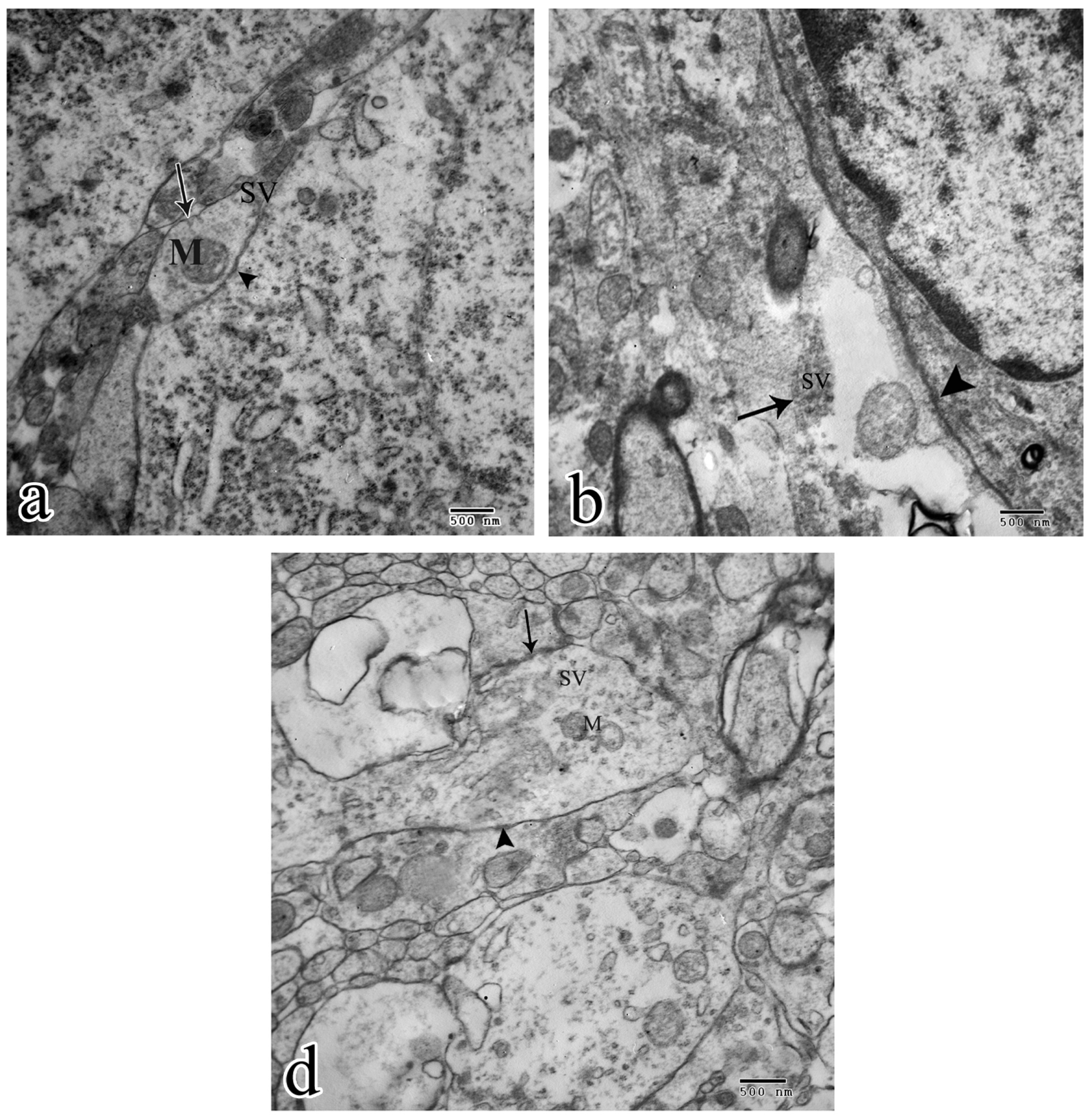

Plate 8: a: An electron photomicrograph showing synaptic contact (arrow head) between the presynaptic terminal (arrow) and the pyramidal neuron of 21 day old control rat. The presynaptic terminal have many synaptic vesicles (SV) of variable sizes and mitochondria (M). (TEM, x14000). b: An electron photomicrograph showing synaptic contact (arrow head) between presynaptic terminal (arrow) and pyramidal neuron of 21 day old rat treated with cadmium. The presynaptic terminal has marked decrease in the amount of the synaptic vesicles (SV). (TEM, x14000). d: An electron photomicrograph showing synaptic contact (arrow head) between the presynaptic terminal (arrow) and a process of pyramidal neuron of 21 day old rat treated with both cadmium and L-carnitine. The presynaptic terminal has many synaptic vesicles (SV) of variable sizes and mitochondria (M). Note that it is closely similar to the control. (TEM, x14000). 


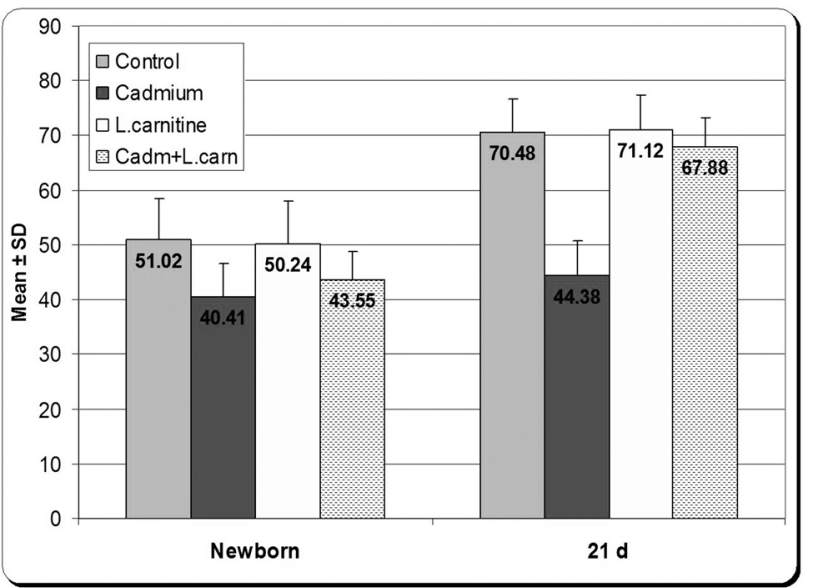

Histogram (1): showing the variation of the granular cell layer thickness in the DG (in microns) at the site of the crest of the studied groups in newborn and $\mathbf{2 1}$ day old albino rats.

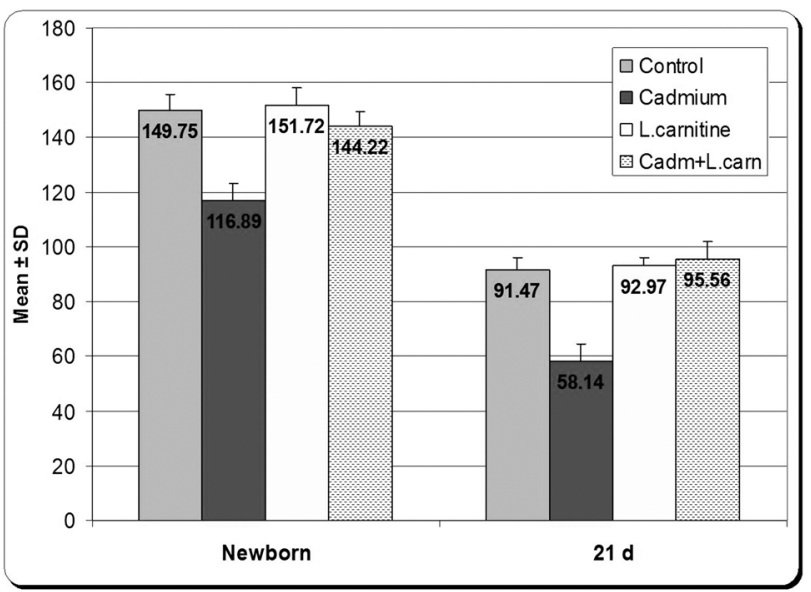

Histogram (2): showing the variation of the granular cell count in the DG per an area $12360 \mu^{2}$ of the studied groups newborn and 21 day old albino rats.

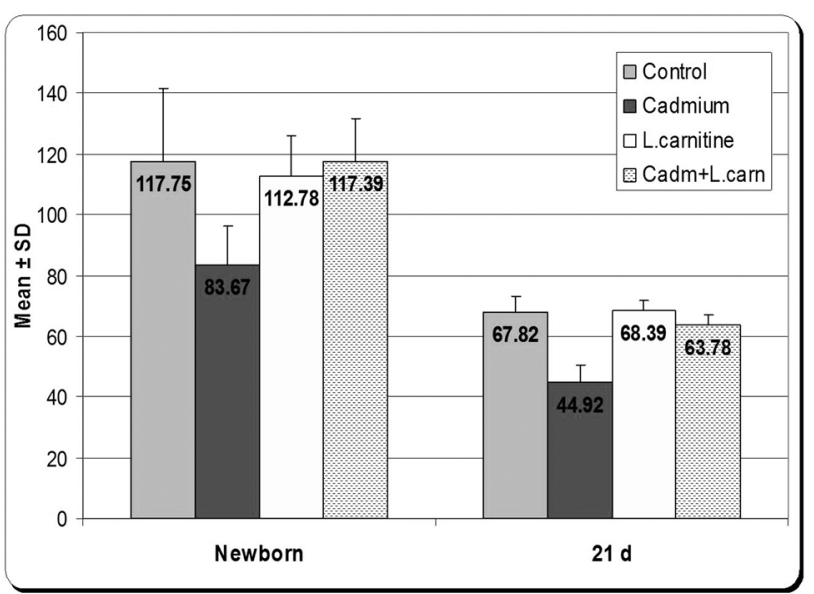

Histogram (3): showing the variation of stratum pyramidale thickness in CA3 field (in microns) of the studied groups in newborn and 21 day old albino rats.

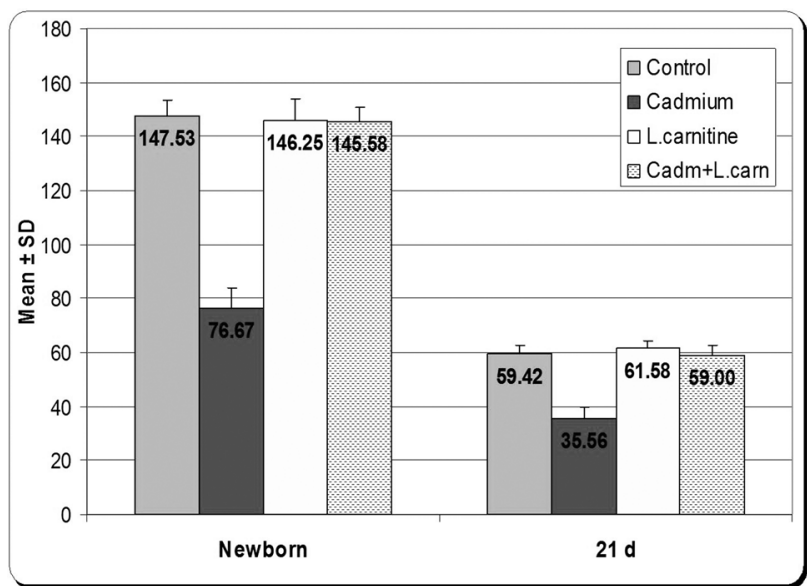

Histogram (4): showing the variation of pyramidal cell count in CA3 field per an area $12360 \mu^{2}$ of the studied groups in newborn and 21 day old albino rats.

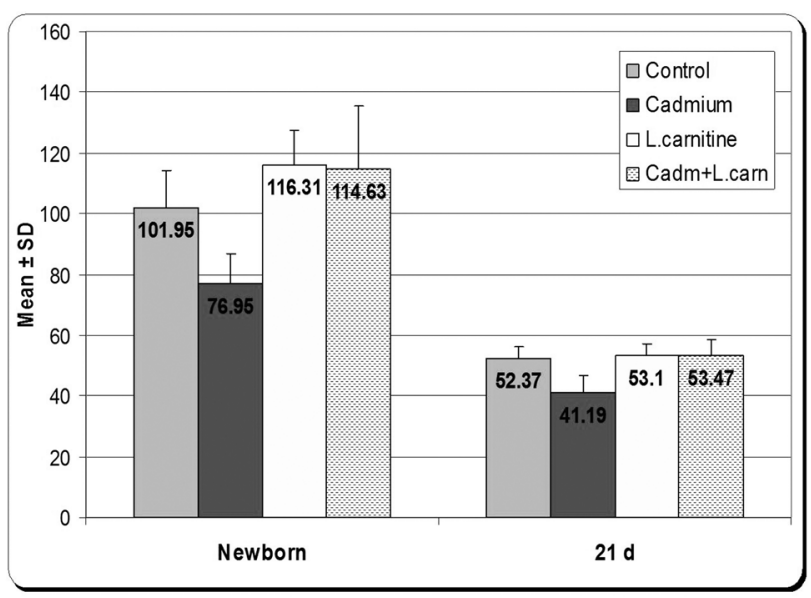

Histogram (5): showing the variation of stratum pyramidale thickness in CA1 field (in microns) of the studied groups in newborn and 21 day old albino rats.

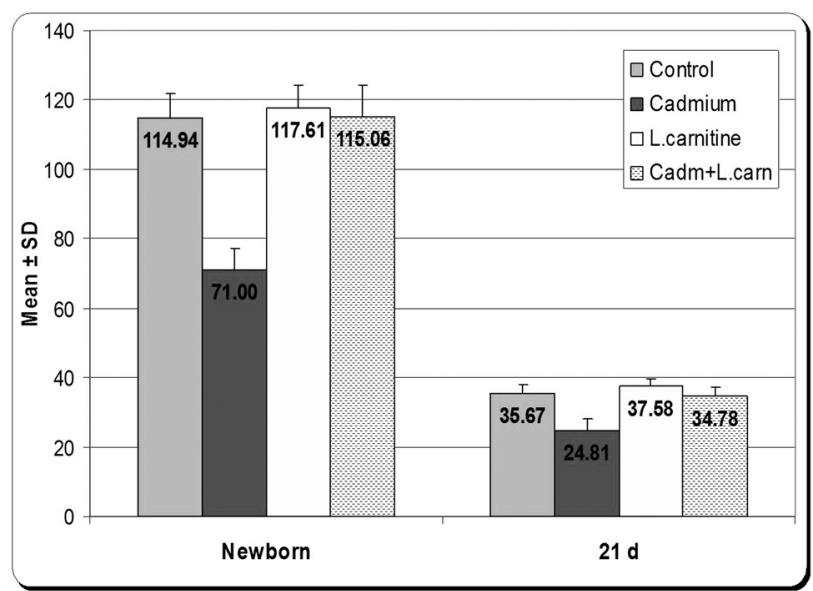

Histogram (6): showing the variation of pyramidal cell count in CA1 field per an area $12360 \mu^{2}$ of the studied groups in newborn and $\mathbf{2 1}$ day old albino rats. 


\section{DISCUSSION}

On entering the body, cadmium will have its detrimental effects on lungs ${ }^{[22]}$, reproductive system ${ }^{[23]}$, liver ${ }^{[24]}$, bone ${ }^{[25]}$, nervous system ${ }^{[2]}$ and kidneys ${ }^{[26]}$. Once it enters the body no treatment can eliminate $i^{[27]}$. Food is generally the largest source of cadmium exposure. The major food groups that contribute to the most cadmium exposure are rice, grains, shellfish, sea food, meat and vegetables ${ }^{[7]}$. Occupational exposure is an important source of cadmium exposure as cadmium is released in the air during the manufacture of numerous industrial products ${ }^{[7,8]}$. L-carnitine was used in our study as an antioxidant protecting against mitochondrial injury ${ }^{[28]}$.

The present study demonstrated the effects of cadmium and L-carnitine on the granule cells of the dentate gyrus and on the pyramidal cells of the CA1 and CA3 fields of the hippocampus (principle cells) of newborn and infant rats. Our study showed that with increased age, the cells changed from densely packed small cells at newborn age to mature cells that have distinct shape and arrangement at 21 day age. These findings are in agreement with previous research $^{[29]}$.

In this study, electron microscopic examination of the principle cells of the three studied regions of the control group revealed the normal structure of the granule and pyramidal cells which showed euchromatic nuclei with their fine granular chromatin and the surrounding cytoplasm was rich in organelles including abundance of free ribosomes, rough endoplasmic reticulum and mitochondria. This observation is similar to earlier studies reported normal principle neurons in hippocampus of adult albino rats ${ }^{[30]}$. In our study the synaptic terminals appeared to contain numerous vesicles, which are responsible for neurotransmitters release ${ }^{[31,32]}$.

In the present research, the histological examination of the cadmium treated group of both ages (newborn and 21 day postnatal) revealed the presence of degenerative changes in the principle cells. Some cells had pyknotic nuclei, while other cells showed vacuolated cytoplasm with darkly stained nuclei. In the newborn rats, these results agrees with previous researchers who reported that cadmium can cross the placental blood barrier causing cell damage in the newborns ${ }^{[5]}$. Regarding the 21 day old group, our results are in accordance with an earlier study indicating the ability of cadmium to be excreted in the milk of the lactating Wistar rats ${ }^{[4]}$. Furthermore, the results of this study are in line with those of a previous research that showed the effect of cadmium on 22 day old rats and reported the presence of degenerative changes in the form of necrosis and atrophy of the hippocampal pyramidal cells $^{[33]}$.

In our study, the electron microscopic examination of cadmium treated rats showed principle cells with degenerative changes in the form of nuclear membrane indentation with condensed nuclear chromatin, damaged mitochondria, vacuolations, dilated rough endoplasmic reticulum, rarified cytoplasm, and reduction in the number of synaptic vesicles at the presynaptic terminals. Indentation of the nuclear membrane and chromatin condensation were attributed to direct toxicity of cadmium on neuronal cells ${ }^{[31]}$. The mitochondrial damage is closely connected with ion homeostasis since a massive rapid influx of calcium into the cell occurs $^{[34]}$. Cadmium affects phosphorylation-oxidative enzymes and disrupts energy cycles in the mitochondria ${ }^{[35]}$. The presence of cytoplasmic vacuolations and dilated rough endoplasmic reticulum could be explained by the lipid peroxidation ${ }^{[31,36,37]}$. Cadmium induces lipid peroxidation by stimulating the production of superoxide anions, and by inhibiting antioxidants such as glutathione peroxidase and superoxide dismutase, thus accumulation of free radicals occurs, damaging the cell and producing chronic diseases ${ }^{[35]}$. The reduced number of presynaptic vesicles caused by cadmium decreases the abilities of nerve conduction and learning and memory ${ }^{[27,32]}$. Cadmium neurotoxicity might be caused by impaired neurogenesis, resulting in markedly reduced neuronal differentiation and axonogenesis, leading to neuronal cell death ${ }^{[38]}$. Previous research studies revealed that cadmium accumulation prior to and at birth can cause irreversible changes in the brain $^{[39,40]}$.

Cadmium can induce microvessel injury which is attributed to oxidative stress ${ }^{[27,41]}$. Cell membrane damage as well as other organelles destruction are followed by an increase in the sodium permeability which exceeds the capacity of ion pump to extrude sodium ${ }^{[31,36]}$. Accumulation of sodium in the cell leads to an increase in its water content leading to swelling.

In this work L-carnitine was given alone to the third experimental group (sham control) and the histological results were more or less similar to those of the control. This proves that L-carnitine has no adverse effect on the hippocampal structure ${ }^{[18]}$. In this study, using L-carnitine together with cadmium (third experimental group) revealed the protective effect of L-carnitine. The majority of the principle cells in the three studied regions had normal appearance with only few cells with darkly stained nuclei and vacuolated cytoplasm. The study of the ultrastructure of principle cells revealed improved results with presence of a few vacuoles, lysosomes and mildly dilated rough endoplasmic reticulum. L-carnitine also improved the degenerative changes in the synaptic terminals and this is attributed to its capability to restore the changes in the phospholipid membrane that occurred due to cadmium toxicity ${ }^{[42]}$. L-carnitine plays important role in $\beta$-oxidation of fatty acids since it transfers long-chain acyl groups from fatty acids into mitochondrial matrix to generate $\mathrm{ATP}^{[43]}$, and prevents mitochondrial injury caused by oxidative $\operatorname{stress}^{[15,18,44,45]}$. Other researchers detected the protective effect of L-carnitine on the hippocampus from the damaging effects of the formaldehyde ${ }^{[14]}$. The healing capacity of L-carnitine was highlighted by a previous study showed that L-carnitine restored choline acetyltransferase activity in the hippocampus of rats with partial unilateral fimbria-fornix transection ${ }^{[46]}$. 
In the newborn rats, the results agree with those of a previous research confirming the capability of L-carnitine to cross the placental blood barrier and reaching the brain of the developing rats providing their protective effects ${ }^{[15]}$. In the 21 day rats, the administration of L-carnitine with cadmium, L-carnitine showed a protective effect on the infants when given to their lactating mothers and this is supported by an earlier study ${ }^{[15]}$.

The present morphometric study demonstrates that the normal thickness of the granular cell layer of the dentate gyrus of 21 day old control rats ranging from $60-80 \mathrm{um}^{[47]}$. The intake of L-carnitine alone showed no difference as compared to the control. The morphometric results also showed that cadmium decreased the measured parameters when compared to those of the control group. The administration of L-carnitine in association with cadmium improved the measured parameters that almost approached the normal values of the control group ${ }^{[45]}$.

\section{CONCLUSION}

Through our study it is concluded that cadmium had toxic effects on the hippocampus in the new born albino rats as it could cross the placental barrier and in the 21 day old albino rat as it could be excreted in milk. Our study also revealed that $\mathrm{L}$-carnitine is protective against the toxic effects of cadmium in both ages as it is capable of crossing placental barrier and excreted in milk.

\section{RECOMMENDATION}

It is recommended to pay attention to the toxic effects of cadmium especially for industrial society with high concentration of cadmium in their environment and we propose treatment with L-carnitine as a protective substance for cadmium poisoning especially for pregnant and lactating women to protect the developing brains of their growing babies. Also it is proposed to modulate the use of phosphate fertilizers that become the largest source of cadmium toxicity.

\section{CONFLICTS OF INTEREST}

There are no conflicts of interest

\section{REFERENCES}

1. Waalkes MP. Cadmium carcinogenesis. Mutat Res 2003; 533:107-120.

2. Méndez-Armenta M, Ríos C. Cadmium neurotoxicity. Environ Toxicol Pharmacol 2007; 23:350-358.

3. Korpela H, Loueniva R, Yrjänheikki E, Kauppila A. Lead and cadmium concentrations in maternal and umbilical cord blood, amniotic fluid, placenta, and amniotic membranes. Am J Obstet Gynecol 1986; 155:1086-1089.

4. Ribas JP, Lopes RA, Sala MA, Ribas LMR, Mattos MGC, Semprini M, Watanabe I, Regalo SCH. Effect of cadmium on rat maxillary molar junctional epithelium during lactation. Int J Morphol 2004; 22:257-262.
5. Stawarz R, Formicki G, Chrobaczyñska M, Czajkowska M, Chryc K, Kuczkowska-Kuzniar A, Massanyi P, Skalba P. Accumulation of cadmium and lead in placenta and amnion of women from upper Silesian region Poland. J Environ Res Dev 2011; 5:871-879.

6. Taylor MD. Accumulation of cadmium derived from fertilisers in New Zealand soils. Sci Total Environ 1997; 208:123-126.

7. Chunhabundit R. Cadmium exposure and potential health risk from foods in contaminated area, Thailand. Toxicol Res 2016; 32:65-72.

8. Järup L. Hazards of heavy metal contamination. $\mathrm{Br}$ Med Bull 2003; 68:167-182.

9. Turner A. Cadmium pigments in consumer products and their health risks. Sci Total Environ 2019; 657:1409-1418.

10. Järup L, Berglund M, Elinder CG, Nordberg G, Vahter M. Health effects of cadmium exposure -- a review of the literature and a risk estimate. Scand J Work Environ Health 1998; 24:1-51.

11. Rajmohan V, Mohandas E. The limbic system. Indian J Psychiatry 2007; 49:132-139.

12. Squire LR. Memory and the hippocampus: a synthesis from findings with rats, monkeys, and humans. Psychol Rev 1992; 99:195-231.

13. Miller MW. Generation of neurons in the rat dentate gyrus and hippocampus: effects of prenatal and postnatal treatment with ethanol. Alcohol Clin Exp Res 1995; 19:1500-1509.

14. Ozmen E, Ozsoy SY, Donmez N, Ozsoy B, Yumuşak N. The protective effect of L-carnitine against hippocampal damage due to experimental formaldehyde intoxication in rats. Biotech Histochem 2014; 89:336-341.

15. Mojtaba E, Davood K, MohammadAli S, Hussein D. Carnitine, metabolism and its pharmacokinetic significance. Int J Biosci 2011; 1:128-140.

16. Sinha M, Manna P, Sil PC. Cadmium-induced neurological disorders and prophylactic role of taurine. J Appl Toxicol 2008; 28:974-986.

17. Ramaswami IS, Kaul DK. The effect of cadmium and selenium on the testis of the desert gerbil Meriones hurrianae Jerdon. J Royal Microscop Soc 1966; 85:297-304.

18. El-Masry AA, Yousef MI, Hussein HK, Kheirallah NAM, Van Straalen NM. L-carnitine protects against oxidative stress induced by sublethal exposure to the synthetic pyrethroid, lambda-cyhalothrin, in rats. Global Adv Res J Environ Sci Toxicol 2014; 3:012-024. 
19. Bancroft JD, Gamble M. Theory and practice of histological techniques. 2008; 6th ed. Churchill Livingstone / Elsevier, Philadelphia, PA, Edinburgh.

20. Kue J. Electron microscopy methods and protocols. New Jersey. Springer. Science \& Business Media 2007; CH: 3, PP:1-8.

21. Dawson B, Trapp RG. Basic and clinical biostatistics. 2001; 3rd ed. New York: Lange Medial books/Mc Graw-Hill.

22. Calabrese EJ, Kenyon EM. Air toxics and risk assessment. Lewis Publishers, Inc., Chelsea, MI, USA; 1991.

23. Nishijo M, Nakagawa H, Honda R, Tanebe K, Saito S, Teranishi H, Tawara K. Effects of maternal exposure to cadmium on pregnancy outcome and breast milk. Occup Environ Med 2002; 59:394-397.

24. Zalups RK, Ahmad S. Molecular handling of cadmium in transporting epithelia. Toxicol Appl Pharmacol $2003 ; 186: 163-188$.

25. Kazantzis G. Cadmium, osteoporosis and calcium metabolism. Biometals 2004; 17:493-498.

26. Johri N, Jacquillet $\mathrm{G}$, Unwin R. Heavy metal poisoning: the effects of cadmium on the kidney. Biometals 2010; 23:783-792.

27. Wang B, Du Y. Cadmium and its neurotoxic effects. Oxid Med Cell Longev 2013; 2013:1-12. Article ID 898034

28. Harper P, Elwin CE, Cederblad G. Pharmacokinetics of intravenous and oral bolus doses of L-carnitine in healthy subjects. Eur J Clin Pharmacol 1988; 35: $555-562$.

29. Mubarak WA. Studies on postnatal development of the hippocampus in the albino rat. Thesis submitted for doctorate degree in basic medical science Anatomy, Assiut University, Assiut, Egypt; 2002.

30. Helal OK, Mousa AM, Kandeel N. Effect of antox on hippocampal structure in male albino rats exposed to lead toxicity: histological and biochemical study. Egy J Histol 2011; 34:808-817.

31. Afifi OK, Embaby AS. Histological study on the protective role of ascorbic acid on cadmium induced cerebral cortical neurotoxicity in adult male albino rats. J Microsc Ultrastruct 2016; 4:36-45.

32. Chen J, Chen YH, Lv HY, Chen LT. Effect of hyperbaric oxygen on lipid peroxidation and visual development in neonatal rats with hypoxia-ischemia brain damage. Biomed Rep 2016; 5:136-140.

33. Kaoud HA, Mekawy MM. Effect of cadmium pollution on neuromorphology and function of brain in mice offspring. Nature Sci 2011; 9:28-35.
34. Radenovic L, Korenic A, Maleeva G, Osadchenko I, Kovalenko T, Skibo G. Comparative ultrastructural analysis of mitochondria in the CA1 and CA3 hippocampal pyramidal cells following global ischemia in Mongolian gerbils. Anat Rec (Hoboken) 2011; 294:1057-1065.

35. Amara S, Douki T, Garrel C, Favier A, Ben Rhouma K, Sakly M, Abdelmelek H. Effect of static magnetic field and cadmium on oxidative stress and DNA damage in rat cortex brain and hippocampus. Toxicol Ind Health 2011; 27:99-106.

36. Emanuel R. Essential pathology. 3rd ed., Cell injury chapter, Lippincott Williams \& Wilkins, USA; 2001.

37. Yan Y, Bian JC, Zhong LX, Zhang Y, Sun Y, Liu ZP. Oxidative stress and apoptotic changes of rat cerebral cortical neurons exposed to cadmium in vitro. Biomed Environ Sci 2012; 25:172-181.

38. Ospondpant D, Phuagkhaopong S, Suknuntha K, Sangpairoj K, Kasemsuk T, Srimaroeng C, Vivithanaporn P. Cadmium induces apoptotic program imbalance and cell cycle inhibitor expression in cultured human astrocytes. Environ Toxicol Pharmacol 2019; 65:53-59.

39. Ishitobi H, Watanabe C. Effects of low-dose perinatal cadmium exposure on tissue zinc and copper concentrations in neonatal mice and on the reproductive development of female offspring. Toxicol Lett 2005; 159: 38-46.

40. Ishitobi H, Mori K, Yoshida K, Watanabe C. Effects of perinatal exposure to low-dose cadmium on thyroid hormone-related and sex hormone receptor gene expressions in brain of offspring. Neurotoxicology 2007; 28:790-797.

41. Shukla A, Shukla GS, Srimal RC. Cadmium-induced alterations in blood-brain barrier permeability and its possible correlation with decreased microvessel antioxidant potential in rat. Hum Exp Toxicol 1996; 15:400-405.

42. Pettegrew JW, Levine J, McClure RJ. Acetyl-L-carnitine physical-chemical, metabolic, and therapeutic properties: relevance for its mode of action in Alzheimer's disease and geriatric depression. Mol Psychiatry 2000; 5:616-632.

43. Marcovina SM, Sirtori C, Peracino A, Gheorghiade M, Borum P, Remuzzi G, Ardehali H. Translating the basic knowledge of mitochondrial functions to metabolic therapy: role of L-carnitine. Transl Res 2013; 161(2):73-84.

44. Chang B, Nishikawa M, Sato E, Utsumi K, Inoue M. L-carnitine inhibits cisplatin-induced injury of the kidney and small intestine. Arch Biochem Biophys 2002; 405:55-64. 
45. Ramezani M, Bahadoran H, Abasi S. Effect of L-carnitin on cadmium induced toxicity in rat embryo hippocampus. International Conference on Environmental and Computer Science IPCBEE 2011; 19:147-150.

46. Piovesan P, Quatrini G, Pacifici L, Taglialatela G, Angelucci L. Acetyl-L-carnitine restores choline acetyltransferase activity in the hippocampus of rats with partial unilateral fimbria-fornix transection. Int J Dev Neurosci 1995; 13:13-19.

47. Duffell SJ, Soames AR, Gunby S. Morphometric analysis of the developing rat brain. Toxicol Pathol $2000 ; 28: 157-163$. 
الملخص العربى

\title{
هل يمكن لمادة لـكارنيتين أن تمنع حدوث الآثار المدمرة الناتجة عن الكادميوم أثناء

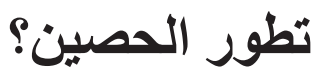

\author{
أيمن صلاح الاين عامر ، فاتن يوسف محمود ، أشرف حمودة عبد الحكيم ، مريم وهبي فيدال

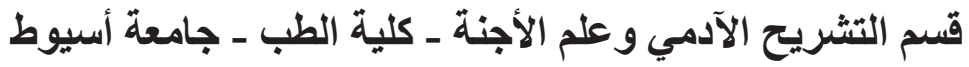

الخلقية: بستخدم الكادميوم في مجالات الحياة اليومية المختلفة. ويلعب الحصين دور ا مهما في عملية تكوين الذاكرة وقد ينأثر هذا نتيجة التعرض للكادميوم. تستخدم مادة ل-كارنيتين كمضاد للأكسدة ولكن دور ها في حماية النسيج العصبي ماز ال غير معروف. الهدف من البحث: الهدف من هذه الدر اسة هو معرفة تأثير التعرض للكادميوم في مرحلة ما قبل وما بعد الولادة علي تركيب الخلايا الرئيسية (الحبييية و الهرمية) في الحصين بالجرذان البيضاء و الدور المحتمل للكارنيتين. مواد وطرق البحث: تم إستخدام إناث الجرذان البيضاء الحوامل وتم تقسيمها إلى مجمو عتين كالآتي: مجموعة الحمل، ومجمو عة الرضاعة. وقد تم تقسيم كل مجمو عة بالتساوي إلى ع مجمو عات فرعية وهي: مجمو عة الحمل: أـ مجمو عة ضابطة لم يتم إعطائها شيئ. بـ مجمو عة تم إعطاءها الكادميوم بدءا من اليوم العاثر للحمل إلى نهاية الحمل. ج- مجمو عة تم إعطاءها ل-كارنيتين بدءا من اليوم السابع للحمل إلى نهاية الحمل. دـ مجمو عة تم إعطاءها ل-كارنيتين بدءا من اليوم السابع للحمل و الكادميوم بدءا من اليوم العاثر إلى نهاية الحمل. مجمو عة الرضاعة: أـ مجموعة ضابطة لم يتم إعطائها شيئ. بـ مجمو عة تم إعطاءها الكادميوم بدءا من يوم الو لادة حتى عمر اب يوم. ج- مجموعة تم إعطاءها ل-كارنيتين بدءا من بدءا من يوم الولادة حتى عمر اب يوم. د- مجموعة تم إعطاءها ل-كارنيتين + الكادميو مبداء من يوم الولادة حتى عمر إبيوم. وقد تم إعطاء الكادميوم بالفم بجر عة ؟ مجم/كجم/اليوم. وتم إعطاء ل-كار نيتين بالفم بجر عة . . ب مجم /كجم/اليوم. وتم جمع عينات الحصين من Y ا ذكر من الجرذان البيضاء المولودة من كل مجمو عة (إجمالي 97 جرذ) في عمرين: حديثي الو لادة و ا ب يوم. وتم تحضير العينات للفحص بالمجهر الضوئي والمجهر الإلكتروني النافذ وللار اسة المورفومترية. النتائج: لقد أظهرت نتائج البحث ما يأتي: ـفي الجرذان التي تم إعطائها الكادميوم في كلا العمرين أظهرت الخلايا الرئيسية في الحصين وجود تغير ات تتكسية في تركيب الخلايا مثل ظهور فجوات في السينوبلازم وتدمير الميتوكوندريا وإنبعاج الغلاف النووي بالمقارنة مع المجمو عة الضابطة. وكذلك أظهرت الدر اسة المورفومترية نقصان ذا دلالة احصائية عالية في عدد الخلايا الرئيسية في الحصين وقلة سمك طبقة الخلايا الرئيسية بالحصين بالمقارنة مع المجموعة الضابطة. ـفي الجرذان التي تم إعطائها كلا من الكادميوم و ل-كارنيتين في كلا العمرين أظهرت الخلايا الرئيسية قلة التأثيرات السلبية بما يقارب مظهر الخلايا في المجموعة الضابطة. 
الخلاصة: يستنتج من هذا البحث أن الكادميوم يدمر الخلايا الرئيسية في الحصين. في حين أن ل-كارنيتين بمكنه أن يحمي ويقلل من الآثار الضارة الناتجة عن الكادميوم. 